\title{
Measuring seasonality at the major spa towns of Hungary
}

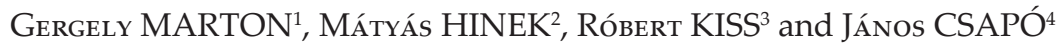

\begin{abstract}
One of the leading tourism products of Hungary is health tourism, where the certain supply segments are influenced by seasonality in different scales. The primary aim of our paper is to survey the seasonality of the 9 spas with the greatest turnover in Hungary with the help of the Gini index. Our research intends to provide an actual picture about the exact measure of seasonality in the highlighted spas of Hungary, due to the overall actuality of the problem and also because no such relevant quantitative research has been dealing with this issue in Hungary yet. The objective reason why these spas were chosen and surveyed is because first of all they are mono profile health tourism centres, where tourists are visiting the settlement exclusively because of the spas, and on the other hand the visitor turnover of the mentioned settlements are significantly higher than the following Hungarian spa towns. We believe that the more we understand seasonality the more we can face with its challenges concerning tourism development. For our seasonality analysis we used the commercial accommodation statistics of the Hungarian Central Statistical Office and to estimate the Gini index we applied the monthly dataset of the guest nights.
\end{abstract}

Keywords: measuring seasonality, Gini index, health tourism, spa towns, Hungary

\section{Introduction}

Taking into consideration both the supply and demand side of the Hungarian tourism industry we can state that its leading tourism product is by no means health tourism. Recently, more than 45 per cent of the guest nights were realized in the rural settlements with spas and if we also include the capital, Budapest, this ratio will exceed 68 per cent (Hungarian Tourism Agency, 2019). Overall, 137 settlements are involved in medical tourism, out of which 14 is qualified as medical places: Balatonfüred, Bük, Debrecen, Eger, Gyöngyös (Kékestető),
Gyula, Hajdúszoboszló, Harkány, Hévíz, Miskolc (Lillafüred), Parád, Sárvár, Sopron (Balf) and Zalakaros. So the country possesses numerous traditional, historical spa settlements besides which a great number of spas were developed or were modernised after the regime change (1989) geared to the demand trends of the $21^{\text {st }}$ century.

Due to the unique physical environment and geological basics, the attractions and endowments of health tourism in Hungary are outstanding even in global perspectives. The most important physical geographical factors are the spatial-geological allocation of the Carpathian

\footnotetext{
${ }^{1}$ Institute of Sport Sciences and Physical Education, University of Pécs. H-7624, Pécs, Ifjúság útja 6. Corresponding author's e-mail: martongergely@gamma.ttk.pte.hu

${ }^{2}$ Institute of Marketing and Tourism, Budapest Metropolitan University. H-1148, Budapest, Nagy Lajos király útja 1-9. E-mail: mhinek@metropolitan.hu

${ }^{3}$ Department of International Tourism and Hospitality, I-Shou University. No. 1, Sec. 1, Syuecheng Rd., Dashu District, 84001 Kaohsiung City, Taiwan. E-mail: robertkiss@isu.edu.tw

${ }^{4}$ Institute of Marketing and Tourism, University of Pécs. H-7622 Pécs, Rákóczi út 80. E-mail: csapo.janos@ktk.pte.hu
} 
Basin, the high values of the geothermic gradient and the quality of the host rock (MichaLKó, G. and RÁtz, T. 2010; Aubert, A. et al. 2012; Gonda, T. 2016; Csapó, J. and Marton, G. 2017; Stupariu, M.I. and Morar, C. 2018). Based on the geological and physical geographical endowments we can differentiate 4 types of medical factors in the Hungarian spa and wellness tourism: medical waters, medical mud, climate therapy and medical caves and mofetta. These four types of medical factors serve as the primary attractions for the supply factors and establishments in Hungary.

Due to the upper mentioned endowments Hungary possessed 529 spas (380 functioning all year and 149 just seasonally) in 2017. A significant amount of these spas provided complex and mixed services with medical, thermal and experience spa services or they served as swimming pools (Csapó, J. and Marton, G. 2017). The most typical forms of spas were the lidos (234), the experience spas (220) and the medical spas (103) (Hungarian Central Statistical Office - HCSO, 2018) (Figure 1).

The role and importance of health tourism in the tourism industry of Hungary is also demonstrated by the fact that amongst the top 10 visited settlements of the country we find (usually) 7 or 8 spa towns (HCSO, 2018). As the National Tourism Development Strategy states, 12.9 per cent of the inbound visits were motivated by wellness or medical reasons. Visitor numbers to Hungarian spas generate more than 40 million visits per year out of which the thermal and medical spas register around 23.0-24.5 million visitors annually (Csapó, J. and Marton, G. 2017).

The degree of seasonality is of key importance at health tourism resorts as well, since in terms of their functioning, certain supply segments are greatly influenced by the annual dissemination of the visitors (mainly the active, outdoor wellness elements) while others (such as the elements of medical tourism)

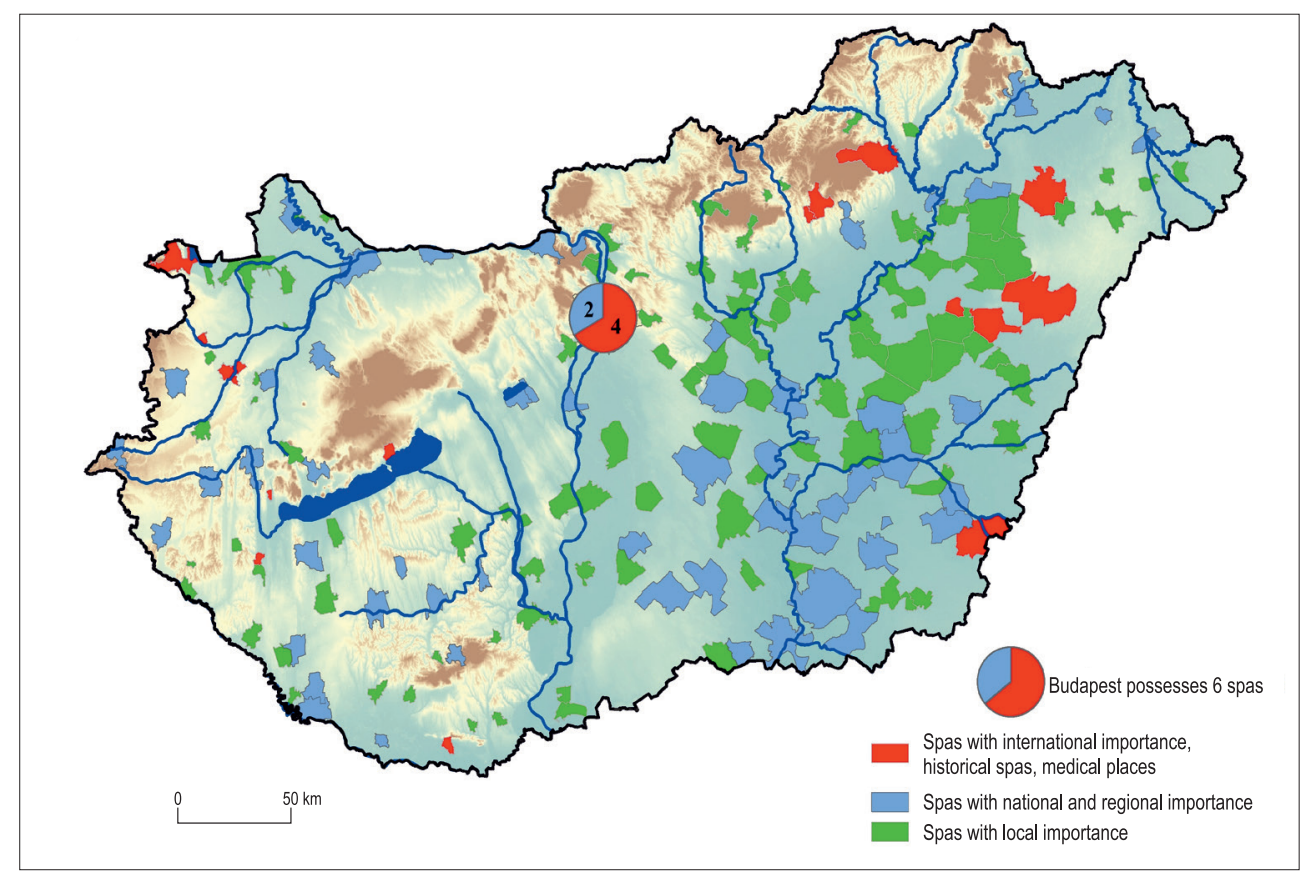

Fig. 1. The spatial allocation and categorisation of spas in Hungary. Source: own editing. 
is less concerned, however, we can see particular processes of seasonality there as well.

Understanding the role and importance of seasonality in the professional tourism planning and development of the country, the primary aim of our paper is to survey the seasonality of the 9 spas with the greatest turnover in Hungary with the help of the Gini index. The objective reason why these spas (Bük, Cserkeszőlő, Egerszalók, Gyula, Hajdúszoboszló, Harkány, Hévíz, Sárvár, Zalakaros) were chosen and surveyed is because first of all they are mono profile health tourism centres (Michalkó, G. and Rátz, T. 2010) where tourists are visiting the settlement exclusively because of the spas, and on the other hand the visitor turnover of the mentioned settlements are significantly higher than the following Hungarian spa towns (Csapó, J. and Marton, G. 2017).

We believe that one of the most important questions of tourism is the topic of seasonality that divides the tourist flow and the generated consumption to different periods such as accentuated or busy and relaxed or less visited ones. The change of the regularly repetitive popular and non-popular periods rises numerous social, environmental and economic (mostly price, revenue-related) questions both on local, regional, national or even international level for the actors of the tourism industry (Duro, J.A. 2016; YANG, Y. et al. 2016; WANG, X. et al. 2019). So, according to the authors, understanding the processes of seasonality gives the chance to find the answers on how to reflect the challenges we face concerning modern tourism development, and so the present article stands as an example for these practical investigations.

Based on the above mentioned the present paper surveys the seasonality of a segment of Hungarian health tourism which possesses a longer season than the average in the country; that is also why this tourism product is handled as an accentuated area in the country's tourism industry. As a novelty, our research intends to provide an actual picture about the exact measure of seasonality in the highlighted spas of Hungary, due to the overall actuality of this issue and also because no relevant literature background was dealing with this problem yet. Although, several types of indexes could be used in measuring the numerical performance of tourism or its segments, such as the tourism index (Aubert, A. et al. 2013) or tourist function index (BorzyszKowski, J. et al. 2016). However, for our seasonality analysis we used the commercial accommodation statistics of the Hungarian Central Statistical Office (for 2018) and to estimate the Gini index we applied the monthly dataset of the guest nights.

\section{Theoretical background and literature review}

The initial study of seasonality was executed by BAR ON, R.V. (1975) using the seasonality range and the seasonality ratio, which are based on the seasonal indices (as percentages) derived from a multiplicative (monthly) model (CoshalL, J. et al. 2015). Later researchers of this topic connected the survey of seasonality to the northern, periphery regions focusing on seasonal patterns of tourism arrivals from different regions and countries (HARTMANN, R. 1986; Snepenger, D. et al. 1990; Butler, R.W. 1994, 2001; Flognfeldt, T. 2001; BAuM, T. and Lundtorp, S. 2001), but we can detect analyses of the Mediterranean region's demand anomalies as well (Sutcliffe, C.M.S. and Sinclair, T. 1980; Donatos, G. and ZAIRIS, P. 1991). The impacts and measure of seasonality were surveyed first in the beginning of the 1990s (HylleberG, S. 1992) and this topic became more popular in the 2000s. Although, LundTorp, S. (2001) started to illustrate several methods for measuring seasonality, this calculation of the periodical flow of tourists remained fashionable for researchers who also adapted the Gini-coefficient as a tool for tracing the temporal changes of the demand (LeE, C. et al. 2008; Bigović, M. 2011; Cisneros-Martínez, J.D. and Fernandez-Morales, A. 2015; FernánDez-Morales, A. et al. 2016; Roselló, J. and SAnsó, A. 2017). 
The theoretical review of CANNAs, R. (2012) related to tourism seasonality provides a thorough explanation about one of the most wellknown problems of tourism mentioning that, according to ButLer, R.W. (1994) seasonality is 'a temporal imbalance in the phenomenon of tourism, [which] may be expressed in terms of dimensions of such elements as numbers of visitors, expenditure of visitors, traffic on highways and other forms of transportation, employment, and admissions to attractions' (Cannas, R. 2012, 41 refers Butler, R.W. 1994). On the other hand Allcock, J.B. (1989) defines it as a concentrated tourism flow in a short period of the year which is a kind of physiological feature of tourism. BAUM, T. (1999) describes seasonality as a problem, which should be tackled on different planning, marketing and operational levels. According to the definition of Hirschey, M. et al. (1993) from an economic point of view there is a rhythmical annual pattern of production, sales, consumption and profitability as indicators. Based on this idea Frechling, D.C. (2001) appraises seasonality as the cyclical fluctuation of a longer period of time, as the subsequent change of the economic indicators. The general approach of Moore, T.W. $(1989,49)$ concludes this phenomenon as 'movements in a time series during a particular time of year that recur similarly each year'. Butler, R.W. (2001) argues that the complexity of seasonality pictures well that it has an effect on the whole of the elements of supply, such as marketing (packages, pricing, distribution), labour force market (quality labour force, abilities and their sustainability), finance, business (cash balance, pricing, attracting investments), the owner management (suppliers, mediators) and all the elements of operation. Out of the comprehensive works dealing with the basic questions, consequences and measurability of seasonality we can mention BAuM, T. and Hagen, L. (1999) and BAum, T. and Lundtorp, S. (2001).

Among the reasons for seasonality BAR ON, R.W. (1975) and HartmanN, R. (1986) distinguished two main ones: natural (climate, seasons, distance from the Equator etc.) and institutionalised (cultural and religious traditions, holidays etc.). For the five main reasons for seasonality ButLER, R.W. (1994, 332-333) indicates 'climate, particularly seasonal variation, human decision factors, notably social, religious or cultural in origin, the sporting seasons, inertia and tradition'. The institutionalised element of seasonality is traditionally a human activity, often fitted to defined times of period such as religious, cultural, ethnic or social factors. The most frequent of all are the official and school holidays. The author also deals with this problem in 2001 indicating that the natural and institutional reasons for seasonality can actuate each other as well (Butler, R.W. 2001).

According to the climatic definition Hylleberg, S. (1992, 4) states that 'seasonality is the systematic, although not necessary regular, intra-year movement caused by changes in weather', moreover climate can result further significant alterations in certain destinations (Amengual, A. et al. 2014). Besides weather (temperature) Hylleberg, S. (1992) also mentions the calendar effect (holidays) and timing (school holidays) as the three most important reasons for seasonality indicating that out of them we can find stable dates, holidays (Christmas), continuously changing, but predictable ones (Easter, Chinese Lunar New Year) and unpredictable ones (such as weather).

The institutionalised reason is more complex and less predictable than the natural one, since it is influenced by culture, religion, ethnic and social factors, the destination, the tourism product or the marketing activities. Butler, R.W. (2001) states that seasonality appears most of all as a problem in tourism which should be handled, however, in some circumstances (such as in remote seasonal rural destinations) it can provide a favourable solution in employment for instance (FlognfeldT, T. 2001). We can also mention among the institutionalised reasons the habits, traditions or the sports seasons so it is obvious that seasonality has been researched from the points of view of sport (Higham, J. and Hinch, T.D. 2002; Kiss, R. 2014) and 
recreational activities (HARTMANN, R. 1986; Butler, R.W. 1994) as well. These researches are highlighting that the uneven distribution at the high season is one of the most convincing problems of recreation and tourism causing ineffectual source utilisation, potential profit loss, social-ecological capacity pressure and administrative difficulties (Manning, R.E. and Powers, L. 1984). The high-level of tourist fluctuation results in a huge negative impact on the environment which has also been one of the key issues in recent seasonal tourism studies (CisnerosMartínez, J.D. et al. 2018).

In the case of the destinations allocated in peripheries the problem of seasonality appears more drastically (BAUM, T. and HAGEN, L. 1999) where first of all the topic of season elongation is surveyed (KoenIG-Lewis, N. and Bischoff, E.E. 2005; CANnAs, R. 2012). The significance of this topic is also strengthened by the data of the Eurostat (2016) that one out of four travels of the Europeans was realised between July and August; and if we have a look at the time length of the travel this concentration is more dynamic. STUPARIU, M.I. and Morar, C. (2018) focused on the customers' fluctuation in a shorter period of time, more precisely, the weekly and monthly streams of tourists' flow in neighbouring spas, which created operational issues at tourism enterprises with high seasonality (CONNELL, J. et al. 2015). Accordingly, accommodations, restaurants or spas were defined by CosHALL, J.et al. $(2015,1604)$ and were named as 'one of the most protracted problems facing managers in the tourism sector'.

Alongside the changes in travel patterns over the past few years, the new trends indicated the strengthening of the spa and medical tourism product (RAmírez de Arellano, A.B. 2007; Connell, J. 2013; Rodrigues, H. et al. 2019). The overall market positions of both wellness and medical tourism has been influenced by the demographic changes (especially in the developed countries) of the last decades, increase in the discretionary income, growing need for recreation and regeneration or simply by financial reasons (HoRowitz,
M.D. et al. 2007; Lunt, N. and Carrera, P. 2010; Csapó, J. and Marton, G. 2017).

Despite the excellent potential, Hungary has to face a growing competition on the international health tourism market. Therefore, the assessment of the competitors is a key task of tourism development (Michalkó, G. and Rátz, T. 2010; Michalkó, G. et al. 2012). In the global content, every country or destination can be regarded as a competitor possessing a health tourism supply of partially or completely international importance. The direct competitors of Hungary are European countries with special attention to its neighbours, specifically, Austria, Slovenia, Slovakia and Romania offering spas of national and international importance and/or other health tourism services, which have undergone significant improvements in the last decade (Lew, A. et al. 2008; YeUnG, O. and Johnston, K. 2017; Stupariu, M.I. and Morar, C. 2018).

Although with a different supply structure, alongside the neighbouring countries, the Czech Republic and Italy have outstanding thermal and medical tourism propositions with international importance on the tourism market. Wellness tourism, the other pillar of health tourism, shows an even more varied picture as natural resources play less significant role. Apart from Hungary's direct neighbours and the other competing destinations, Poland and Russia need to be regarded as serious competitors in terms of existing and future wellness tourism potential (LEw, A. et al. 2008; Csapó, J. and Marton, G. 2017).

Nevertheless, health tourism is a rather popular scope in researches in the country especially in domestic (Hungarian) publications much less work has been carried out in English. Besides the comprehensive work of SмIтH, M.K. and Puczkó, L. (2017) we can highlight spatial and structural papers (Aubert, A. et al. 2010, 2013; Michalkó, G. and RÁtz, T. 2010; JónÁs-BERKi, M. et al. 2015), tourism oriented real estate development (Michalkó, G. and RÁtz, T. 2010) and demand analyses (Sмітн, M.K. and Puczkó, L. 2015), guest flow analyses (Sulyok, J. and Mester, T. 2014) or papers 
and researches dealing generally with wellbeing and quality of life (Sмiтн, M.K. and Diekmann, A. 2017) or taking into consideration regional aspects (RÁTZ, T. and MichALKó, G. 2011; Sprah, L. et al. 2014).

Such works analysing the seasonality of Hungarian tourism are present only in a limited number of publications in the Hungarian scientific literature which is especially interesting as the country's tourism flow is concentrated both in space (Budapest and Lake Balaton) and time (summer high season). Sulyok, J. and Kiss, K. (2006) analysed seasonality in general in the country while Sulyok, J. and Mester, T. (2014) were focusing on the turnover of commercial accommodations in connection with seasonality. DÁvid, L. and Tóth, G. (2009) published a research on seasonality on the example of a Hungarian mountain range (Mátra mountains) and Marton, I. et al. (2001) analysed thermal tourism as a possible tool for the elongation of the season. Our research continues the product centred approach of the upper mentioned publications focusing on the least seasonal tourism product of the country.

\section{Materials and methods}

The Gini index (GINI, C. 1912) is basically based on the Lorenz curve, which shows the distribution of a studied variable (e.g. income or health, or in our case: guest nights) (Figure 2). The value of the Gini index is the ratio of the area closed by the 45-degree line (the line of equality) and the Lorenz curve (A) correlated to the size of the complete area of the triangle symbolising the total inequality $(A+B)$, so $\mathrm{G}=\mathrm{A} /(\mathrm{A}+\mathrm{B})$. The size of the area representing complete inequality is $\mathrm{A}+\mathrm{B}$, so 0.5 , accordingly $\mathrm{G}=\mathrm{A} / 0.5$, and $\mathrm{G}=2 \mathrm{~A}$. So, the area of the Gini index is twice the area closed up by the 45 -degree line and the Lorenz curve (A).

If the analysed variable where we look at the frequency is continual, then from the perspective of geometry, the area between the Lorenz curve and the line (A), or the area under the Lorenz curve (B) can be determined

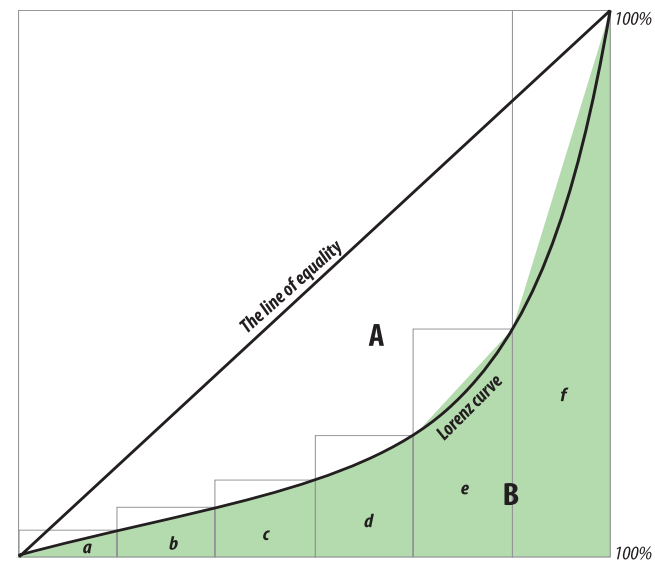

Fig. 2. The estimation of the area under the Lorenz curve (B) with trapezoids (grey areas) when the frequency variable is discrete (e.g. months). Horizontal axis $=$ the ratio of the certain months related to all the months (in \%); Vertical axis = the ratio of guest nights related to the number of the total (annual) guest nights (from the months with the smallest turnover to the one with the greatest, cumulated). Source: Own editing, 2016.

with integral calculus. This, however, happens only at the rarest of cases, in practice we usually meet a discrete variable, as in our case, when we examine the distribution of guest nights based on monthly data. In this case, the area under the Lorenz curve can be given with an approximate estimation as the sum of the trapezoids fitted with one side to the curve (see Figure 2, where area ' $\mathrm{B}$ ' is approximately the sum of the area of the grey trapezoids: $a+b+c+d+e+f)$.

The Gini index is widely applied to measure the seasonality of tourism since it represents the seasonal inequalities of tourism flow with a quantitative method (Fernández-Morales, A. 2003; FernándezMorales, A. and Mayorga-Toledano, M.C. 2008; Bigović, M. 2011; Sulyok, J. and Mester, T. 2014). Since we would like to measure the seasonality from the inequalities of a 12 months data set we can use the following formula in order to calculate the Gini index (Sulyok, J. and Mester, T. 2014): 


$$
G=1-\sum_{i=1}^{12}\left(X_{i}-X_{i-1}\right) \cdot\left(Y_{i}+Y_{i-1}\right),
$$

where $i$ means the certain months, $X_{i}$ is the cumulated share from the 12 months and $Y_{i}$ is the share of the cumulated guest nights from the annual total guest nights of the months lined up in an increasing sequence by the number of guest nights.

For our seasonality analysis we used the commercial accommodation statistics of the Hungarian Central Statistical Office (2018) and in order to estimate the Gini index we applied the monthly dataset of the guest nights. According to the HCSO the two main type of the accomodations are the business accommodations and the non business accomodations. Business accomodations can be divided into two further categories:

1. commercial accommodations (hotels, special hotels, e.g. health, wellness, garni and apartment hotels; pensions, campings, holiday homes, hostels and youth hostels);

2. other business accommodations (standalone buildings or a demarcated part thereof intended not solely for the purpose of accommodation services, where the number of rooms used for this purpose is not more than 8 , and the number of beds is not more than 16).

According to the HCSO, the non-commercial accommodations are 'accommodation for holiday and youth tourism and mountain shelter' (HCSO, 2019).

In our study we studied only the commercial accommodations. These statistics are available from 2000 which is rather fortunate since the first great wave of state-supported investments in the spa towns started from this year. It is also important to add that only the monthly guest nights of the commercial accommodations is available in the Hungarian statistics while no relevant data is available concerning the visitor number of the spas or the other business accommodations, that is the basic reason why we chose statistical data of the commercial accommodations in our calculations. The Gini index can only be used with monthly or even more refined data. The guest nights of the commercial accommodations are also an adequate indica- tor because it records well the formation of the tourism activity in the analysed destination. Seasonality can be counted based on other data (number of the guests, accommodation receipts) as well, however, traditionally the calculation of this index is based on guest night datasets.

It is important to note that while in 2016 the commercial accommodations of the studied spa towns had 36,000 bed places, the other business accommodations had almost an additional 26,000 beds. In that year, the total number of the guest nights in the commercial accommodations in the studied spa towns were higher than 4.5 million, while in the other business accommodations they were not quite than 765,000 (16.6\% of the commercial accommodations). Nevertheless, the performance of the other business accommodations is not negligible, but it is not critical in assessing the seasonality of the spa towns. The capacity and overnight stays of other business accommodations indicate that seasonality is likely to be higher for this type of accommodation, given that these accommodations typically do not operate all year round. However, no data are available to verify this expectation.

The novelty of the research is that the authors focus and draw the attention on the importance and applicability of the Gini index in terms of tourism seasonality surveys and also that no such research has been carried out so far in order to numerically support the seasonality of the tourism of the accentuated spa towns in Hungary. The results of our surveys are not only useful for the academic world, but when seasonality is presented by exact mathematical calculations than useful data are provided for the stakeholders and decision makers of the spas and the municipalities in order to understand one of the greatest issues of the Hungarian tourism industry, the temporal and spatial allocation of the tourists.

\section{Results: the evaluation of the seasonality change of the major Hungarian spa towns}

According to our results the seasonality of the analysed spa towns decreased overall in 
the last 16 years. If we study the commercial accommodation data of the spa towns all in one, they show a 27.7 per cent decrease of seasonality in all the 9 spa towns between 2000 and 2016 (Figure 3). While in 2000 the value of the Gini index was 0.279 (taking into consideration all the analysed spa towns), it decreased to 0.171 by 2016 .

The decrease, however, was not balanced. In the analysed period there were years when seasonality increased in the commercial accommodations of the spa towns. 2005 was such a year where seasonality grew slightly $(2.3 \%)$ compared to the previous year's results, but such era was between 2008-2010 and 2013 and 2015 where seasonality grew by 12.5 and 8.8 per cent respectively, compared to the previous year's data. At the same time from 2000 to 2016 the decrease of seasonality can be detected in numerous years. We identified the greatest decrease in 2011 and in $2014(-12.7 \%$ and $-14.9 \%$ respectively, compared to the previous year's data), but the 8.5 per cent decrease in 2004 was much higher than the average. Since the decrease of seasonality was characteristic for more years than the increase, we detected an overall 30 per cent decrease in the Gini index, and so in seasonality, between 2000 and 2016.

Fitting a linear trend to the aggregated data of the spa towns we see the slightly decreasing trend of seasonality (see Figure 3). The insertion of the linear trend line is relatively good, the value of the $\mathrm{R}^{2}$ coefficient of determination is 0.68 . The average degree of the annual decrease of the Gini index is -1.7 per cent.

Seasonality formed quite differently in the certain spa towns. The Gini index decreased the least in Hévíz (-9.2\%), Hajdúszoboszló $(-16.7 \%)$, Harkány $(-18.0 \%)$ and Gyula $(-24.5 \%)$ which it is also due that these 4 traditional spa towns possessed a developed commercial accommodation background already in 2000. That is why in these settlements' seasonality did not decrease at such measure than in those spa towns where the certain developments started after the millennium. Since these settlements represent a significant guest flow in comparison to the others, they influence quite significantly the formation of the combined

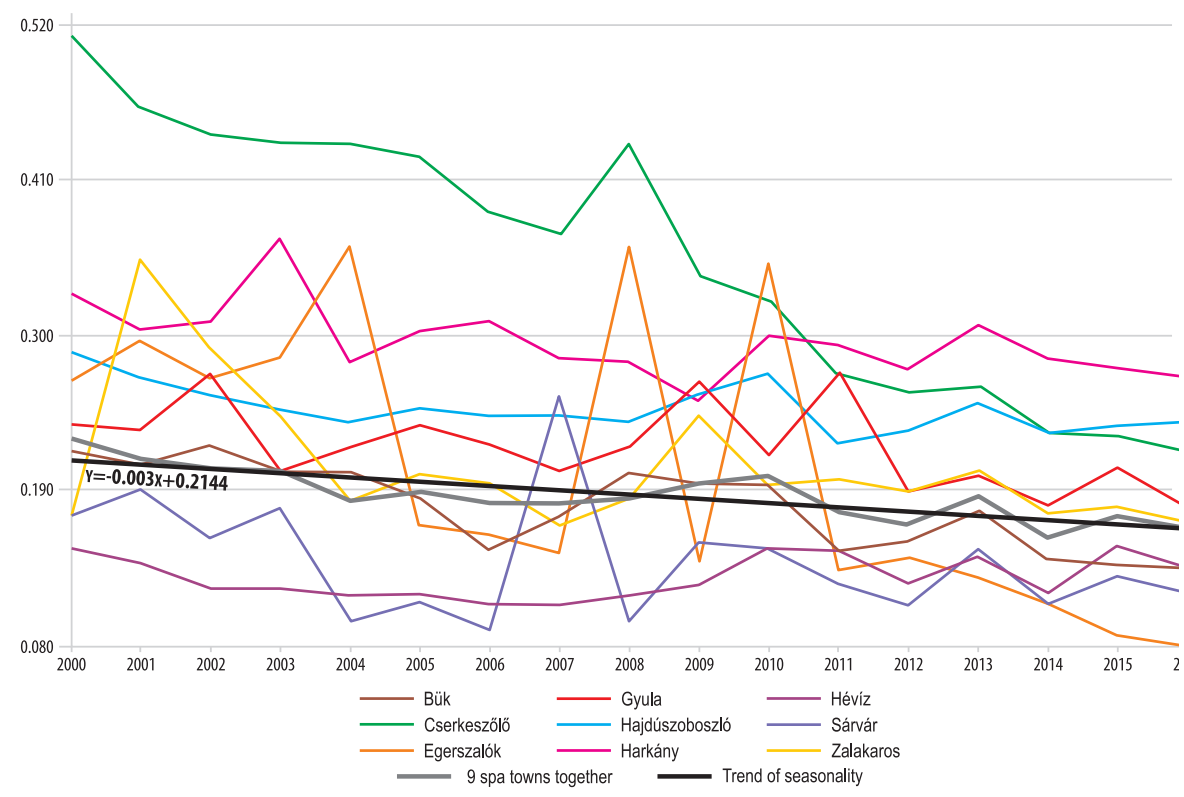

Fig. 3. The formation of seasonality of the analysed spa towns. Source: Based on HCSO database, own calculation. 
Gini index as well. Nevertheless, seasonality decreased the most in Egerszalók $(-70.1 \%)$, Cserkeszőlö (-57.2\%) and Zalakaros (-50.7\%) as well as we could detect a significant decline (more than $-30 \%$ ) in Bük and Sárvár between 2000 and 2016.

The formation of seasonality is worth compared with the formation of the capacities, especially because on the national level in the researched period the number of the rooms of the commercial accommodations grew with 31 per cent and the number of the beds by more than 20 per cent. A much faster increase was experienced in the analysed 9 spa towns (Table 1). The number of beds grew from 24,400 the other spa towns. If we do not analyse the increase ratio than concerning the absolute numbers of the capacity of the commercial accommodations Hajdúszoboszló is leading with more than 8,000 bed places.

Taking into consideration the increase of capacities (supply) the increase of the demand is much faster. The number of nights at commercial accommodations grew from 2.6 million in 2000 to 4.6 million $(+75 \%)$ by 2016 . Except for Harkány, the demand grew at every analysed spa town with remarkably high data at some settlements (Table 2). In Egerszalók, this increase was more than 270-fold since as a new spa there were practically very low commercial

Table 1. The change of the capacity of the commercial accommodations in the analysed spa towns, in bed places

\begin{tabular}{l|c|c|c|c}
\hline \multirow{2}{*}{ Spa towns } & \multicolumn{2}{|c|}{$\begin{array}{c}\text { Number of bed places in } \\
\text { commercial accommodations }\end{array}$} & $\begin{array}{c}\text { Growth in bed places in } \\
\text { number between } 2000 \\
\text { and } 2016\end{array}$ & $\begin{array}{c}\text { Growth in bed places } \\
\text { in } \% \\
(2000=100 \%)\end{array}$ \\
\cline { 2 - 3 } Egerszalók & 2000 & 2016 & 1,088 & 6,144 \\
Cserkeszőlő & 18 & 1,106 & 500 & 168 \\
Sárvár & 730 & 1,230 & 1,947 & 310 \\
Zalakaros & 927 & 2,874 & 1,987 & 188 \\
Gyula & 2,267 & 4,254 & 346 & 113 \\
Harkány & 2,620 & 2,966 & $-1,030^{*}$ & $-30^{*}$ \\
Bük & 3,401 & 2,371 & 1,729 & 149 \\
Hévíz & 3,533 & 5,262 & 2,494 & 151 \\
Hajdúszoboszló & 4,892 & 7,386 & 2,199 & 136 \\
Total & 6,032 & 8,231 & 11,260 & 146 \\
\hline
\end{tabular}

*Harkány: decrease. Source: Hungarian Central Statistical Office (HCSO) 2018, and own editing.

(2000) to 35,700 (2016) so almost with 50 per cent, which is more than twice the national increase. Analysing the towns one by one it turns out that in Egerszalók this increase was more than 60 per cent, however, it started from a very low basis data.

The number of accommodation capacity grew significantly in Sárvár as well, from 900 places in 2000 to nearly 3,000 by 2016 . In Zalakaros the capacity of the commercial accommodations grew with 88 per cent, in Cserkeszőlő 68 per cent, while Bükk and Hévíz grew their capacities with 50 per cent. This increase meant in Hévíz nearly 2,500 new bed places with which the town emerges from guest nights in 2000 which grew to more than 200,000 by 2016 . The number of guest nights almost quadrupled in Sárvár (2000: 130,000; 2010: 485,000) and tripled in Cserkeszőlő (2000: $44,000 ; 2016: 147,000)$. At the same time the increase was not so remarkable from a high basis. In Hévíz the number of guest nights grew by 33 per cent, but it means a 259,000 increase in absolute numbers compared to as in 2000. In Hajdúszoboszló, the increase was 47 per cent with an absolute increase of 300,000 guest nights. The greatest increase in absolute numbers could be detected in Bük $(+340,000$ guest nights) preceding Hajdúszoboszló $(+300,000)$, Zalakaros $(+297,000)$ and Hévíz $(+259,000)$. 
Table 2. The change of the guest nights in commercial accommodations in the analysed spa town

\begin{tabular}{l|c|c|c|c}
\hline \multirow{2}{*}{ Spa towns } & \multicolumn{2}{|c|}{$\begin{array}{c}\text { Number of guest nights } \\
\text { in 1,000 }\end{array}$} & $\begin{array}{c}\text { Growth of guest nights } \\
\text { between 2000 and 2016, } \\
\text { in 1,000 }\end{array}$ & $\begin{array}{c}\text { Growth of guest nights } \\
\text { in \% } \\
(2000=100 \%)\end{array}$ \\
\cline { 2 - 4 } & 2000 & 2016 & 199.6 & 27,258 \\
\hline Egerszalók & 0.7 & 200.3 & 102.6 & 333 \\
Cserkeszőlő & 44.1 & 146.7 & 355.7 & 374 \\
Sárvár & 129.7 & 485,4 & 296,6 & 246 \\
Zalakaros & 203.7 & 500.3 & 144.7 & 165 \\
Gyula & 222.0 & 366.7 & $-32.5^{*}$ & $-15^{*}$ \\
Harkány & 224.2 & 191.7 & 340.1 & 194 \\
Bük & 360.7 & 700.8 & 299.9 & 147 \\
Hajdúszoboszló & 638.0 & 937.8 & 259.3 & 133 \\
Hévíz & 796.8 & $1,056.1$ & $1,966.0$ & 175 \\
Total & $2,619.9$ & $4,585.9$ & & \\
\hline
\end{tabular}

*Harkány: decrease. Source: Own editing.

\section{Conclusions}

The seasonality of the guest flow of the spa towns is much smaller than the seasonality of tourism in general in Hungary. This is an important phenomenon in the tourism industry of such a destination where the majority of tourists are still visiting Hungary concentrated both in time and space. While the Gini index of the guest nights at commercial accommodations on the national level is 0.25 than this aggregate value is more than 30 per cent less, in 2016 (0.17 at the analysed spa towns). We can conclude that the spa town function results expressly favourably to seasonality.

The other important lesson is that the investments and developments in the last 16 years effectively decreased the seasonality of the guest flow of the spa towns. These developments typically included investments in supply covering mainly the tourism infrastructure and supra-structure of the spas and also the accommodation and guest catering structure of the settlements, with a special emphasis on the development of tourism services as well. The drop of seasonality was the greatest at the spa towns carrying out significant investments and developments (Cserkeszőlő, Egerszalók) which is partly due to the statistical impact and partly it shows that the implemented investments managed to extend the season.
The experiences of the 'new spa towns' are confirmed by the data of the traditional ones (Hévíz, Hajdúszoboszló). In these latter ones seasonality did not decrease at the same level as in the case of the new ones, since they had from earlier times those supply elements which were promoting their requisition during the complete year. The new investments strengthened the four seasons-long supply, so the decrease of seasonality was not remarkable. In the future significant decline of seasonality is not expected in the case of the new spa towns so we should not forecast further significant decrease in the Gini index on the national level either, because of the former realisation of the four seasons-long supply.

Comparing the dynamics of the demand and supply we can also see that in the spa towns the increase of the capacity of the commercial accommodations ( $+50 \%)$ was significantly exceeded by the increase of the demand $(+75 \%)$. Therefore, the utilisation of the available capacities is less seasonal, so the demand requisitioned the capacities in a much more expanded time scale in the season. Since the decrease of seasonality took place besides a significant increase of commercial accommodation capacity, the expansion of the turnover possibly made an impact on the anticipated return of the investments as well. This finding is supported by the rise of the occupancy 
rate of the commercial accommodations: the average occupancy rate of the rooms in the 9 spa towns was 44 per cent in 2009, and 56 per cent in 2016. This increase of room occupancy in the commercial accommodations increased almost continuously in the reviewed period except for Harkány, where no spa improvements have been made in the reviewed years.

Based on the findings of our study we can state that in the analysed period demand has increased significantly and in parallel, seasonality has declined in the studied spa towns. It seems to be proved that the extensive developments of the spa towns were successful, the accommodation capacity and the number of guest nights were growing in a remarkable extent and the utilization of the capacities also increased slightly.

As for some limitations of the study the authors think that, as a future research direction, the detailed analysis of changes in individual settlements should be further analysed to obtain a more accurate picture on the settlement level as well. Parallel with this, the guest data of other accommodations would also be required to test seasonality (to obtain the more detailed picture). We consider the present study as a simple quasi-longitudinal study, but we cannot clearly explain here that there is a correlation between the implemented developments and the spa towns' tourism and seasonality. This topic could be a further issue in these researches. As the last aspect of further research directions we should also measure the improvements in the quality of services in the spa towns and as an explanatory variable it should be built into a larger model, parallel with other parameters, such as the changes in income or concerning the economic cycle.

Acknowledgements: The project has been supported by the European Union, co-financed by the European Social Fund Grant no.: EFOP-3.6.1.-16-201600004 entitled by Comprehensive Development for Implementing Smart Specialization Strategies at the University of Pécs. „The research was financed by the Higher Education Institutional Excellence Programme of the Ministry for Innovation and Technology in Hungary, within the framework of the 4th thematic programme "Enhancing the Role of Domestic Companies in the Reindustrialization of Hungary" of the University of Pécs."

\section{REFERENCES}

Allcock, J.B. 1989. Seasonality. In Tourism Marketing and Management Handbook. Eds.: WITT, S.F. and Moutinho, L., London, Prentice Hall, 387-292.

Amengual, A., Homar, V., Romero, R., Ramis, C. and Alonso, S. 2014. Projections for the 21 ${ }^{\text {st }}$ century of the climate potential for beach-based tourism in the Mediterranean. International Journal of Climatology 34. 3481-3498. Doi: 10.1002/joc.3922

Aubert, A., Csapó, J., Pirkhoffer, E., Puczkó, L. and Szabó, G. 2010. A method for complex spatial delimitation of tourism destinations in South Transdanubia. Hungarian Geographical Bulletin 59. (3): 271-287.

Aubert, A., Jónás-Berki, M. and Marton, G. 2012. Spatial organisation and management characteristics of health tourism in Hungary. Central European Regional Policy and Human Geography 2. (2): 27-36.

Aubert, A., JónÁs-Berki, M. and Marton, G. 2013. Tourism index as an indicator of the intensity of tourism. Acta geographica Slovenica 53. (2): 342-363.

Bar ON, R.V. 1975. Seasonality in Tourism. A Guide to the Analysis of Seasonality and Trends for Policy Making. Technical Series N. 2., London, The Economist Intelligence Unit Ltd.

BAUM, T. 1999. Seasonality in tourism: understanding the challenges. Tourism Economics 5. (1): 5-8. Doi: $10.1177 / 135481669900500101$

BAUm, T. and Hagen, L. 1999. Responses to seasonality: the experiences of peripheral destinations. International Journal of Tourism Research 1. (5): 299-312. Doi: 10.1002/(SICI)15221970(199909/10)1:5<299::AID-JTR198>3.0.CO;2-L

BAUM, T. and LundTORP, S. 2001. Seasonality in Tourism. Oxford UK, Pergamon.

BIGović, M. 2011. Quantifying seasonality in tourism: a case study of Montenegro. Academica Turistica 4 (2): 15-32.

BorZYSZKowsKi, J., MARCZAK, M. and ZARĘBSKI, P. 2016. Spatial diversity of tourist function development: The municipalities of Poland's West Pomerania province. Acta geographica Slovenica 56. (2): 267-276.

ButLER, R.W. 1994. Seasonality in Tourism: Issues and Implications. In The State of the Art. Ed.: SeAton, A.V., Chichester UK, Wiley, 332-339.

BUTLER, R.W. 2001. Seasonality in tourism: issues and implications. In Seasonality in Tourism Eds.: BAUM, T. and Lundtorp, S., Oxford UK, Pergamon, 5-22.

Cannas, R. 2012. An overview of tourism seasonality: Key concepts and policies. AlmaTourism 5. 40-58.

Cisneros-Martínez, J.D. and Fernandez-Morales, A. 2015. Cultural tourism as tourist segment for reducing seasonality in a coastal area: The case study of Andalusia. Current Issues in Tourism 18. 765-784.

Cisneros-Martínez, J.D., McCabe, S. and FernandezMorales, A. 2018. The contribution of social tourism to sustainable tourism: A case study of 
seasonality adjusted programmes in Spain. Journal of Sustainable Tourism 26. (1): 85-107.

Connell, J. 2013. Contemporary medical tourism: Conceptualisation, culture and commodification. Tourism Management 34. 1-13.

Connell, J., Page, S.J. and Meyer, D. 2015. Visitor attractions and events: Responding to seasonality. Tourism Management 46. 283-298.

Coshall, J., Charlesworth, R. and Page, S.J. 2015. Seasonality of overseas tourism demand in Scotland: A regional analysis. Regional Studies 49. (10): 1603-1620.

Csapó, J. and Marton, G. 2017. The role and importance of spa and wellness tourism in Hungary's tourism industry. Czech Journal of Tourism 6. (1): 55-68. Doi: 10.1515/cjot-2017-0003

DÁvid, L. and Tótн G. 2009. Hegyvidéki területek szezonalitásának problémái a Mátravidék példáján (Problems of seasonality in mountainous areas through the example of Mátra Region). Földrajzi Közlemények 33. (1): 33-41.

Donatos, G. and Zairis, P. 1991. Seasonality of foreign tourism on the Greek Island of Crete. Annals of Tourism Research 18. (3): 515-519. Doi: 10.1016/01607383(91)90060-O

Duro, J.A. 2016: Seasonality of hotel demand in the main Spanish provinces: Measuring and decomposition exercises. Tourism Management 52. 52-63.

Eurostat 2016. Tourism in the EU. Last retrieved: 9 June 2019. Available at https://ec.europa.eu/eurostat/news/ themes-in-the-spotlight/tourism-2016

Fernández-Morales, A. 2003. Decomposing seasonal concentration. Annals of Tourism Research 30. (4): 942-956. Doi: 10.1016/S0160-7383(03)00090-2

Fernández-Morales, A. and Mayorga-Toledano, M.C. 2008. Seasonal concentration of the hotel demand in Costa del Sol: A decomposition by nationalities. Tourism Management 29. (5): 940-949. Doi: 10.1016/j.tourman.2007.11.003

Fernández-Morales, A., Cisneros-Martínez, J.D. and $\mathrm{MCC}_{\mathrm{ABE}}, \mathrm{S}$. 2016. Seasonal concentration of the tourism demand: Decomposition analysis and marketing implications. Tourism Management 56. 172-190. Doi: 10.1016/j.tourman.2016.04.004

Flognfeldt, T. 2001. Long-term positive adjustments to seasonality: consequences of summer tourism in the Jotunheimen Area, Norway. In Seasonality in Tourism. Eds.: BAum, T. and LundTORP, S., Oxford UK, Pergamon Press, 109-117..

Frechling, D.C. 2001. Forecasting Tourism Demand: Methods and Strategies. Oxford, ButterworthHeinemann.

GinI, C. 1912. Variabilità e mutabilità. In Memorie di metodologica statistica. Eds.: Pizetri, E. and Salvemini, T. Reprinted in 1955. Rome, Libreria Eredi Virgilio Veschi.

Gonda, T. 2016. A turisztikai termékfejlesztés elméleti alapjai (Theoretical principles of touristic products development). Szekszárd, PTE KPVK.
Hartmann, R. 1986. Tourism, seasonality and social change. Leisure Studies 5. (1): 25-33. Doi: $10.1080 / 02614368600390021$

Higham, J. and Hinch, T.D. 2002. Tourism, sport and seasons: the challenges and potential of overcoming seasonality in the sport and tourism sectors. Tourism Management 23. (2): 175-185. Doi: 10.1016/ S0261-5177(01)00046-2

Hirschey, M., Pappas, J. and Whigham, D. 1993. Managerial Economics: European Edition. London, The Dryden Press.

Horowitz, M.D., Rosensweig, J.A. and Jones, C.A. 2007. Medical tourism: globalization of the healthcare marketplace. Medscape General Medicine 9. (4): 1-33. Available at http://www.ncbi.nlm.nih.gov/ pmc/articles/PMC2234298/ (Accessed 10 July 2017) Hungarian Central Statistical Office (HCSO) 2018. Available at: www.ksh.hu

Hungarian Central Statistical Office (HCSO) 2019. Available at: http://www.ksh.hu/docs/hun/modsz/ modsz45.html

Hungarian Tourism Agency 2019. Available at: https://mtu.gov.hu/cikkek/egeszsegturizmus (Accessed 10 September 2019)

Hylleberg, S. (ed.) 1992. Modelling Seasonality. New York USA, Oxford University Press.

Jónás-Berki, M., Csapó, J., PÁlfi, A. and Aubert, A. 2015. A market and spatial perspective of health tourism destinations: The Hungarian experience. International Journal of Tourism Research 17. (6): 602-612. Doi: 10.1002/jtr.2027

KIss, R. 2014. The geographical position, system and modelling of golf tourism. Hungarian Geographic Bulletin 64. (2): 201-220.

Koenig-Lewis, N. and Bischoff, E.E. 2005. Seasonality research: the state of the art. International Journal of Tourism Research 7. (4-5): 201-219. Doi: 10.1002/jtr.531

Lee, C., Bergin-Seers, S., Galloway, G., O'Mahony, B. and McMurray, A. 2008. Seasonality in the Tourism Industry: Impacts and Strategies. CRC for Sustainable Tourism Pty Ltd. Australia. Management Handbook. Cambridge, Prentice Hall.

Lew, A., Hall, C.M. and Tiмотнy, D.J. 2008. World Geography of Travel and Tourism: A Regional Approach. Oxford, Elsevier.

Lundtorp, S. 2001. Measuring Tourism Seasonality. In Seasonality in Tourism. Eds.: BAuM, T. and LUNDTORP, S., Oxford UK, Elsevier.

Lunt, N. and Carrera, P. 2010. Medical tourism: Assessing the evidence on treatment abroad. Maturitas 66. (1): 27-32.

Manning, R.E. and Powers, L. 1984. Peak and off use: redistributing the outdoor recreation/tourism load. Journal of Travel Research 23. (2): 25-31. Doi: 10.1177/004728758402300204

Marton, I., Sarudi, Cs. and Nyáriné Budvig, A. 2001. A termálturizmus a szezon-hosszabbítás szolgálatában (The thermal tourism serving the 
extension of season). In Vidékfejlesztés - környezetgazdálkodás - mezógazdaság. A 43. Georgikon Napok Tudományos Konferencia kiadványa. Eds.: Palkovics, M. and Kondorosiné Varga, E., Veszprém, Veszprémi Egyetem Georgikon Mezőgazdaságtudományi Kar.

Michalkó, G. and Rátz, T. 2010. Hungarian spa destinations in the tourism-oriented property market. Hungarian Geographical Bulletin 59. (2): 131-146.

Michalkó, G., Rátz, T. and Hinek, M. 2012. Spatial differences in Hungarian medical tourism supply based on service providers' online presence. Hungarian Geographical Bulletin 61. (1): 31-47.

Moore, T.W. 1989. Handbook of Business Forecasting. London, Gower.

Ramírez de Arellano, A.B. 2007. Patients without borders: The emergence of medical tourism. International Journal of Health Services 37. (1): 193-198.

Rátz, T. and Michalkó, G. 2011. The contribution of tourism to well-being and welfare: the case of Hungary. International Journal of Sustainable Development 14. (3-4): 332-346.

Rodrigues, H., Brochado, A. and Troilo, M. 2019. Listening to the murmur of water: essential satisfaction and dissatisfaction attributes of thermal and mineral spas. Journal of Travel and Tourism Marketing 36. Doi: 10.1080/10548408.2019.1633986

Roselló, J. and Sansó, A. 2017. Yearly, monthly and weekly seasonality of tourism demand: Adecomposition analysis. Tourism Management 60. 379-389. Doi: 10.1016/j.tourman.2016.12.019

Sмith, M.K. and Diekmann, A. 2017. Tourism and wellbeing. Annals of Tourism Research 66. 1-13. Doi: 10.1016/j.annals.2017.05.006

Sмiтн, M.K. and PuczKó, L. 2015. More than a special interest: Defining and determining the demand for health tourism. Tourism Recreation Research 40. (2): 205-219. Doi: 10.1080/02508281.2015.1045364

Sмiтн, M.K. and Puczkó, L. 2017. The Routledge handbook of health tourism. London-New York, Routledge.
Snepenger, D., Houser, B. and Snepenger, M. 1990 Seasonality of demand. Annals of Tourism Research 17. (4): Doi: 10.1016/0160-7383(90)90037-R

Sprah, L., NovaK, T. and FridL, J. 2014. The wellbeing of Slovenia's population by region: comparison of indicators with an emphasis on health. Acta geographica Slovenica 54. (1): 67-87.

Stupariu, M.I. and Morar, C. 2018. Tourism seasonality in the spas of Romania. GeoJournal of Tourism and Geosites 22. (2): 573-584. Doi: 10.30892/gtg.22225-312

Sulyok, J. and KIss, K. 2006. A magyarországi turizmus szezonalitása, 2000-2004. (Seasonality in tourism in Hungary, 2000-2004). Turizmus Bulletin 10. (1): 57-69.

Sulyok, J. and Mester, T. 2014. A magyarországi turizmus szezonalitása - A kereskedelmi szálláshelyek vendégforgalma (Seasonality in tourism in Hungary - Tourist arrivals at the commercial accommodations). Turizmus Bulletin 16. (3-4): 85-91.

Sutcliffe, C.M.S. and Sinclair, T. 1980. The measurement of seasonality within the tourist industry: An application to tourism arrivals in Spain. Applied Economics 12. (4): 429-441. Doi: 10.1080/00036848000000004

WANG, X., SUn, J. and Wen, H. 2019. Tourism seasonality, online user rating and hotel price: A quantitative approach based on the hedonic price model. International Journal of Hospitality Management 79. 140-147.

Yang, Y., Mueller, N.J. and Croes, R.R. 2016. Market accessibility and hotel process in the Caribbean: The moderating effect of quality-signalling factors. Tourism Management 56. 40-51. Doi: 10.1016/j.tourman.2016.03.021

YeUnG, O. and Johnston, K. 2017. Global Spa and Wellness Economy Monitor. Miami FL, Global Wellness Institute. 
